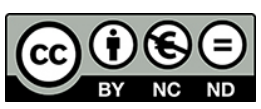

\title{
A systemic approach of the vulnerability in the post-industrial society: the case of the bee colonies collapse disorder
}

\author{
Sylvie Guillerme, GEODE - Géographie de l'Environnement, UMR 5602 CNRS-UTM, 31000 \\ Toulouse, sylvie.guillerme@univ-tlse2.fr
}

The decline of pollinators' populations - and domestic bee in particular - going up for the last two decades is the subject of an extensive literature (Chagnon, 2008). The scale as well as the number of countries affected by this phenomenon is a cause for serious concern. The researches completed so far at the international level were not able to highlight all the threats to which bees are confronted and the precise causes of the bee colonies collapse disorder remain unexplained (Haubruge and al., 2006; EFSA, 2008; van Engelsdorp and al., 2009). The report of the AFFSA of 2009 entitled "Mortalities, collapses and weakening of the bee colonies" identifies almost forty possible causes for the vulnerability of the bee colonies. The phenomenon is now attributed to multifactorial causes which interact with each other (Gunasekara and al., 2007). To determine the relative share of each one remains a major challenge for research, difficult to assess not only because of the number of possible combinations is endless (Anderson and al., 2008) but also because the study of these factors supposes the mobilization of very varied scientific disciplines (Potts and al., 2010).

Intensification of agricultural practices in France like monocropping based on the use of chemical plant protection products generated a simplification of the rural landscapes since 1962 with the implementation of the CAP (Common Agricultural Policy). Since the 1950s1960s in particular, the pollen and nectar resources are little by little depleted both quantitatively and qualitatively due to the degradation of ecosystems by regroupings of agricultural lands, loss of hedges and clearing of undergrowth, increasing use of chemical herbicides and pesticides for the field crops, early mowing of hayfields, and growth of urbanization. Therefore France has experienced a significant reduction of the tree component in agrarian areas (Baudry and al., 2003). In many arable crop production areas there has been widespread suppression of hedges and scattered trees between 1960 and 1980. The resulting impoverishment of agrobiodiversity - fauna and flora - (Burel and al., 2009) deprives bees of diversified food resources further stressing the colonies and making them more vulnerable (Keller and al., 2005).

A work undertaken in the arable crop areas of the Gers region (France) questioned the outlook of farmers and bee-keepers about their interaction with bees, melliferous resources related to the wooded landscape as well as the evolution of the agricultural and apiarian practices and knowledge: past and present diversity of practices, perceptions of the changing landscapes, issues and challenges of the farming and beekeeping activities were among the topics addressed in an open-ended way that build the relationships between farmers and bee-keepers (Guillerme and al., under press). Based on these data and involving a systemic approach the present paper proposes to draw a parallel between the evolution of the honeybee colonies and that of the rural post-industrial society.

While in terms of societal organization the industrial society is grounded in tangible elements (raw materials and machinery), the key feature of the post-industrial society is subordinated to intangibles ones (knowledge and information) (Touraine, 1969; Bell, 1976). This paradigm shift is source of paradoxes, by moving from a rural, agricultural society into an urban, 
industrialized one. The post-war period promoted the intensification of agriculture. But at present the durability of the system is challenged. On one hand, farming remains anchored in the producing function of agriculture and doesn't always consider measures in favor of biodiversity as being able to be part of the production system. On the other hand the recent proposals to minimize biodiversity erosion do not take into account the effects of development on agriculture and the constraints / pressures imposed on farmers.

Rural activities like agriculture and bee-keeping depend on biodiversity for their development and their perpetuation. Indeed, bees are an essential element of the biodiversity by ensuring the pollination of many crops and fruit trees. Thus $80 \%$ of the crops (essentially fruit-bearing, vegetable, oleaginous and protein crops) are dependent on pollinating insects. In 2005, assessment of the contribution made by pollinating insects - including bees - to global agricultural production is estimated at 153 billion euro, i.e. $9.5 \%$ of the global food production. This pollination services provided by bees is a common good between the beekeepers, the farmers and the society as a whole. If bees disappear, the production of food resources runs the risk of being severely compromised. And it is an important part of the functioning capacity of ecosystems which appeared to be weakened.

The polysemic concept of vulnerability puts more emphasis on the exposure of the issues and the fragility of societies (Léone and Vinet, 2006, Reghezza, 2006, Becerra, 2002). The postindustrial society seems relatively helpless in dealing with the disappearance of bees, which reinforces the idea of a "vulnerable society". This may take several forms: from the standpoint of a "physical" vulnerability (not only in terms of damage but also of exposure profile), from that of a "social" vulnerability (which covers the ability to withstand events and the resilience of societies) and lastly considering a systemic vulnerability, which analyzes the domino effects and takes into account simultaneously the structural, as well as socio-economic or functional damage to society as a whole.

This approach proposes a change in viewpoint on the complexity of the relationship between man and nature, considered from the perspective of the diachronic perception of the stakeholders about the territorial and landscapes dynamics and their issues at stake. A mechanism of mirror effect displays various paradoxes of the society and its expectations.

\section{References}

Anderson, D. and East, I.J., 2008, The latest buzz about Colony Collapse Disorder. Science 319, 724725.

Baudry J., Jouin A. (Coord), 2003, De la haie aux bocages, organisation, dynamique et gestion, INRA Paris, $435 \mathrm{p}$

Becerra S., 2002, Vulnérabilité, risques et environnement : l'itinéraire chaotique d'un paradigme sociologique contemporain », VertigO - la revue électronique en sciences de l'environnement.

Bell, D., 1976, Vers la société post-industrielle, Robert Laffont, Paris,

Burel F, Garnier E, Amiaud B, Aulagnier S, Butet A, Chauvel B, Carré G, Cortet J, Couvet D, Joly P, Lescourret F, Plantureux S, Sarthou JP, Steinberg C, Tichit M, Vaissière B, van Tuinen D, Villenave C, 2009, Rapport "Agriculture et Biodiversité »Chapitre 1. Les effets de l'agriculture sur la biodiversité, INRA ESCO, $139 \mathrm{p}$

Chagnon, M., 2008, Causes et effets du déclin mondial des pollinisateurs et les moyens d'y remédier. Fédération Canadienne de la Faune. Bureau régional du Québec, $70 \mathrm{p}$

EFSA, 2008, Bee Mortality and Bee Surveillance in Europe - A Report from the Assessment Methodology Unit in Response to Agence Française, EFSA, 
http://www.efsa.europa.eu/EFSA/efsa_locale-1178620753816_1211902584688.htm［Accédé Février 23, 2010].

Gunasekara, A.S., Truong T., Goh K.S., Spurlock F., and Tjeerdema R.S., 2007, Environmental fate and toxicology of fipronil. Journal of Pesticide Science 32(3):189-199.

Haubruge E., Nguyen B.K, 2006, Le dépérissement de l'abeille domestique, Apis mellifera L., 1758 (Hymenoptera : Apidae) : faits et causes probables, NFDG, 59 (1), pp. 3-21.

Keller I., Fluri P., Imdorf A., 2005, Pollen nutrition and colony development in honey bees, Part II, Bee World, 86: 27-34

Léone F., Vinet F. (dir.), 2006, La vulnérabilité des sociétés et des territoires face aux menaces naturelles. Analyses géographiques. Géorisques 1, équipe GESTER, Université P. Valéry, Montpellier 3

Potts S.G., Biesmeijer J.C., Kremen C., Neumann P., Schweiger O. and William Kunin W.E,, 2010, Global pollinator declines: trends, impacts and drivers, Trends in Ecology and Evolution, Vol.25 No.6, 345-353

Reghezza M., 2006, La vulnérabilité, un concept problèmatique, in Léone F, Vinet F. (dir.), 2006, $L a$ vulnérabilité des sociétés et des territoires face aux menaces naturelles. Analyses géographiques. Géorisques 1, équipe GESTER, Université P. Valéry, Montpellier 3, pp. 35-41

Touraine, A., 1969, La société post-industrielle. Naissance d'une société, Denoël, Paris

I Van Engelsdorp, D. et al., 2009, Colony Collapse Disorder: A Descriptive Study. PLoS ONE, 4, 1-17. 
